\title{
テーマ別 抄録
}

\section{都市・集落に関する論文抄録}

John M. Hunter: An Exercise in Applied Geography. Geographical Planning in Urban Areas for the 1960 Census of Ghana. Geography, Vol. XLVI, Part I, Jan. 1961, pp. 1 8

1960 年,ガーナに抢いてははじめて,かなり信頼 の抢けるセンサスが行なわれたが，それ以前は不確 奏なセンサスが多く，特に第 1 回の 1891 年から 19 21 年までの間は，觳類の粒で男，コヤスガイで女の 数定表わすという万法すら行なわれていた。1960年 のセンサスに際しても, 国土の1/3 は 62,500 分の 1 の地図ができておらず，へき地の統計は信用できな い.このセンサスで一番問題となつたのは, enum- eration area の設定であり，各地区を機能，部族， 自然条件，人口，形などの総合的判断に基ついて区 分してある. 特に都市, 例えばアクラの調査地区分 割に留しては，かなりくわしい地図ものつており， 比較的未知のアフリカの現状の一端を知ることがで きる、後進地域におけるセンサス，あるいは都市問 題の文献としてこの庥用地理研究は興味があると思 るれる.

Emrys Jones: Sociological Aspects of Population Mapping in Urban Areas. Geography, Vol. XLVI,

Part I, Jan. 1961, pp. 9〜17

前述のガーナにおける研究とは異なり，これは先 進国における一例である。著者は Belfastに㧍ける 人口と宗教分離現象の 2 者について, ward 別の分 布図と enumeration district 別の分布図を比較して いる．当然のことながら両者は大いに異なつて抢り， 一目膫然, enumeration district 別の方方真実に近

いことがわかる. Belfast $の$ enumeration district 設 定は，単に人口だけでなく，宗教などの社会的現象 女考慮されているので，各地域単位の等質性に多少 の問題はあるにせよ，地域单位の数が多い場合は一 応さしつふえのない結果が得られるであるう。

George KIsH : Centuriatio, The Roman Rectangular Land Survey. Surveying and Mapping, Vol. XXII,

No. 2, June 1962, pp. 233 244

2000年ほど前になされた centuriatio は今日のイ タリアでも各地に見られる農村景観である.アメリ カの General Land Survey のように必ずしも東 西・南北厅向をとつているわけではないが，整然と した正方形の道路網は，植生・家屋形態など走除く と，アメリカ中西部ときわめて類似している．著者
は多くの写真や地図を使いその現状を報告するとと もに，士地区画の方法，測量器具などについてくわ しく記している．多くのラテン語がでてきて多少読 みづらいが，それだけにイタリアの集落景観・発達 の研究者にとつてはてごろな論文であろう。

V. G. Davidovich : Satellite Cities and Towns of the USSR. Soviet Geography : Review and Translation, March 1962, pp. 3〜35

この論文はソ連に打ける衛星都市を概観したもの である・まず，現存の衛星都市を通勤十文化サービ スによつて規定されるものと，文化サービスのみに よつて規定されるものとの 2 つ分けている. 1959 年 1 月 15 日現在，このような規定による衛星都市 goroda-sputniki は全国で 319 存在し，その他きわ めて多くの小規模なものがあり, 両者合わせて 1,700 万の人口があつた。

多くの表や図が使用され，特に都市規模のさまざ まな分析・比較や分布図は有用である。モスクワや 
レニングラードの衛星都市の分布状態は，欧米や日 本のそれとよく似ているが，きわめて多数の衛星都 市が，10 数コの中心都市の周りに，関東平野ぐらい の広さにわたつて分布しているドンバスの様相は一 見に值する.ソ連の衛星都市の約半分は，既存の集 落と関係なしに形成された。.モスクワにも数十の衛 星都市(町)が存在し，2 時閒以上の距離の所にまで のびている.

これらの現状分析にたつて，訫画面に関してもさ
まざまな助言を行なつている. 現在のように鉄道沿 いに延々と都市化を進めるのをさけ，ゆつくりと計 画的に人口の再配置を行ない，住居と仕事場を近づ けるようにすべきである; 森林を切り開いて衛星都 市を作るのは好ましくなく，それはレクリエーショ ン用にすべきである; 新しい工場の建設は $3 \sim 4 \mathrm{~km}$ 以内の市外に作るようにし, 新らしい衛星都市を作 らなくてすむようにするなどがその例である.

G. Ye. Mrshchenko : Satellite Cities and Torens of Moscow. Soviet Geography, March 1962, pp. 35 43

これはモスクワの現状と計画案について述べたも のである.市町村合併によつて市域が拡大してきた が, 1935 年当時の予想をはるかに上回つてモスクワ の人口が增加し，郊外を走る環状高速道路まで拡大 された行政市域 $875 \mathrm{~km}^{2}$ でさえも，現在の 500 万の 人口に，4〜5階のアパートで 1 人当たり最低 $15 \mathrm{~m}^{2}$ の床面積を確保するだけでいつぱいであり，それ以 上の発展は望めない. 郊外の森林はレクリエーショ
ンに用いられるべきで，そこに衛星都市老新たに建 設するのは適切でない，かくて著者は衛星都市は少 なくとも都心から $50 \mathrm{~km}$ はなれた所に立地させるこ とを提案し，完全に独立した都市にすることは不可 能であるとの推測のもとに，地上鉄道や道路によつ て都心と結びつける案を述べている. 前述の Davidovich の論文と合わせて読むと有益である.

Elisabeth Lichtenberger: Wien. Eine stadtgeographische Skizze. Geographische Rundschau, Juni 1962, Nr. 6, pp. 236 246

本題に大る前に，簡単にウィーンの位置について のべ，本題では現存する景観にあらわれた都心部， 古い街，郊外の新しいアパート群，郊外の田園住宅 地などを美しい写真で示しながら都市発達の過程を まず論述し，さらに土地利用図を中心に地域構造を 説明している，都市機能のダイナミックな様相や定
量的分析はほとんどなされていないが，景観論や地 域発達過程の観点からは，かなり要領よくまとまつ た論文といえよう。人口 200 万に満なないウィーン の市街地が，中心より半径ほぼ $10 \mathrm{~km}$ の範国にまで ひろがつていることなど，興味ある事実も多い．

David WARD : The Pre-Urban Cadaster and the Urban Pattern of Leeds. A.A.A.G., Vol. 52, No. 2, June 1962, pp. 150 166

Leeds に例をとつたこの研究は，都市化以前の地 籍困に表われた土地区画と，現存する建物・道路の 位置やタイプを関連づけたものである.一般に，土 地区画がさかつた場合。あるいは建設者の規模が 小さかつた場合に，現存する都市景観は相対的によ
り小規模で，かつコンパクトになるということを実 証している. そして，このような研究法は西ヨーロ ッパの多くの都市について適用できると著者は述べ ている.

Leo F. Schnore : Municipal Annexations and the Growth of Metropolitan Suburbs, 1950 60. American Journal of Sociology, Vol. LXVII, No. 4, Jan. 1962, pp. 406 417

1960 年度の合衆国センサスでは，合併された市町 村のデータものせられているが，それを利用して 1950 年のデータとくらべた研究である. 郊外化の顕
著なことは有名な事実であるが，合併さ礼た地区を 中心都市の人口に加えない場合，郊外の人口增加率 は中心都市の 40 倍にもなる。そうでない場合には， 
わずか 4.5 倍でしかない。また，最近 50,000 人以 上になつた新しい都市の郊外における増加率は，19 世紀前半頃その規模に達した都市のそれよりも，約 1.5 倍に達している，この研究では，合衆国全体た
けでなくいくつかの地区，あるいは都市別にも同 様の分析がなされており，合衆国の都市化研究にと つてきわめて有用である.

(正井泰夫)

\section{都 市 関 係（特に世界の都市化）}

世界の都市化を考察するうえに，これまでひとつ の支障であつたのは，都市地域と統計的地域単位の 混乱およびそれに関する国際的無統一の問題であつ た. 1959 年に California 大学の International Urban Research は，合乑国の Standard Metropolitan Area (SMA) に準ずるものとして World Metropolitan Area (MA's) 苍設定したが，これはこの点に 関する重要な進歩であり，都市の世界比較にひとつ の新しい展開点を与えるものであつた。ここに取り 上げた論文の $2 つ も ，$ 明らかに出発点をてこに求め ており，他の論文は，いずれもそれ在内容的に補足 するりのを持つ、そして，それらを通して，常識的 ではあるが重要な次のような事実が確認される。

都市化の進行は現在なお世界的な傾向であるが, その速度はいわゆる先進地方に遅く，後進地方が急 速にそれに接近しつつある。英国を初め，西欧な上゙ の工業国家群の都市化は，都市勢力の相互競合盛衰 や，都市核心地域より周辺地域への人口移動などの 形をとつて，対外的にも対内的にも，既存都市の再 編成の段階に大つている傾向加強い。しか子，英国 などでは，これらの人口分散の動きすらもいくつか の逆行的都市により統一を乱されている.

これに区して，後進地方諸国に打ける現在の都市 化は，都市人口の急速な成長を伴ないながらの経済 的，社会的分野に捺ける都市勢力そのものの急速な 機能拡張である. それを西欧化ないし西欧的近代化
とする表現が適切か否かは論者により一致しない. しかし，いずれにせよ南米では無人の荒野への完全 な計画都市の新設があり，他厅，ふるい起源を持つ アフリカでは，在来機構と伝統との閒の矛盾に悩み ながら，なおその伝統の基盤に立つてアフリカ独自 の型式意持つ急速な都市化が破奏に進行中である。

さらに，重要な事はこれらの急速な都市化を支え るものはここに挙げられる例に関するかぎり，む しろ工業化ではなく，行政機能を初めとする中心地 的管理機能ないし 3 次産業機能である事実である. 英国における最も典型的な都市の拡大が最近 $2 つ 0$ 大学都市に見られるというのも，この点に関して極 めて示唆的な事であるが，工羓化の遅れた後進地才 の諸例に执いてさえも，その目覚ましい都市化の内 容は Primate city の成長傾向を多分に含んだワ イトカラ一的都市人口の急速な増大である. それは， 今世紀初頭以来の先進国工業の発展に伴なつての植 民政策の徹底と，商品化経済の滲透による第 1 次生 産の飛躍と。そこに流れ込む国外資本の強化などに よる都市化とむしろ共通に繫る基盤を持つている。 しかし，現在のそこには，あくまで民族的自律の推 進を背景とする中心地機能の躍進があり，上述の過 程をへてもたらされた現地人口の所得水準ないし生 活様式の変化に基づいての 3 次産業の発達がある点 に大きな意味が見出だせる。

GibBs, Jack P. : Growth of Individual Metropolitan Areas ; A Global View. Ann. Assoc. Amer. Geogr.,

Vol. 51, No. 4, 1961, pp. 380 391

I URが発表した 1064 の世界のMAのうち，そ の $85 \%$ の 906 につては，かなり正確に最近の成 長を観察しうる。これはMAを持つ 105 の国のうち 82 国にあたる。世界MAの 1941 年〜 53 年の年間平 均人口增加率は $2.4 \%$ であるが，南アフリカの 5.3 $\%$ 支筆頭に，近東 $4.5 \%$ ，中米 $4.0 \%$ ，北了フリカ $3.7 \%$ ，南米 $3.5 \%$ ，南アジア $3.4 \%$ などの值が大
きく，反面，西欧 $1.0 \%$ ，東欧 $1.9 \%$ なよ゙が低值を 示している. 各地域のMAを増加率段階による暴加 百分比に整理すると既工業化国の成長停滞と非工業 化国の著しい成長はさらに明瞭である。すなわち， 人口減少のMAが東欧で $19.6 \%$ ，西欧 $9.4 \%$ ，北米 $3.8 \%$ 含まれ，特に西欧では人口増加 $2 \%$ 以下のM Aが $85.2 \%$ 含まれている. 反対に人口増加率 $10 \%$ 
以上のMAを持つのは，南・北アフリカ，東アジア などであり，5\%以上増加のMAについても南アフ リカ $46.7 \%$ ，中東 $38.4 \%$ や，中・南米，北了フリ 力の各 $20 \%$ 前後が目立つ。

最近の都市成長は，地域的，国家的条件に結びつ く傾向が次第に強まつているために，個別的な都市 の成長を超えて地域間にはつきりした傾向差が見ら れる。 それは地域平均成長率の值として見ると上述 のごとく必ずしも大きな開きでなく，反面，地域内
の標淮偏差は 12 地域中 6 地域で平均値の $1 / 2$ を超え る.しかし，分散分析の形で見ると，地域間の地域 内に対する分散比 $\mathrm{F}$ は $35: 1$ の大きな開きを示し, また，地域平均とその最高・最低值の間にも各 0.85 , 0.62 の強い相関がある。これらは，地域と都市の成 長がかなりの関連を持つ事を示し，特に極值の予測 性に関しては重要な手掛りであろう，最後に個々の MA拉よび国家の年間成長率が付表として揭げてあ る.

Schnore, Leo F.: Metropolitan Development in the United Kingdom. Econ. Geogr., Vol. 38, No. 3, 1962, pp. 215 233

英国は I URによる58のMAを持つが，その地 域的分布は，52 が England と Wales に集中して いる. その地理的位置は 31 が海岸その他外洋船舶 と接触しうる位置にあり, 13 が河川・運河に臨んで いる．英国MAの海運的所産は明膫であり，鉄道時 代以後の発展による内陸MAは 12 にすぎない，必 然的にそれらの経済機能においても，18は港として 特に優れ，より一般的な型式としては約 40 が工業 機能に特色を示している。

1951 年 56 年の MA成長率では，人口增加を示 したMAが 50 ある。最も急速な成長を見せたもの は，2つの古典的大学都市 Cambridge (10.6\%)， Oxford (10.0\%) である.しかし，一般的には人口増 加は緩慢で，中位数で年間 $0.43 \%$ 在示し，45 に上 る大半のMAは $1.0 \%$ 以下である. 個々のMAの成 長を見ると，その地域的分布，地理的位置，経済的
機能の 3 要素に関して，いずれにも一定の傾向を認 めえない全く不統一の変化が英国の特色であり，M $\mathrm{A} の$ 規模順位と成長率の相関は一0.35にすぎない.

MA成長の型式を観察するために，核心市域と外 縁地域の人口変化の関係により，相対分散，絶対分 散，相対集中，絶対集中の 4 型を考えて見る。人口 の分散傾向は 47 の MAに認められ，之の半数の 23 は核心市域の人口が減少した絶対分散である。集中 性格のものが 10 のA 見られるのは注目され， 特に Leeds-Bradford, Swasea-Neath の2MAは, 外縁部の人口減少圭伴なう絶対集中である。これら の集中型MAの存在も英国の1特色であろうし，ま た，この種の成長型についてり，地域分布，地理的 位置，経済機能などに関するなんらの統一的な傾向 が認められない。

Bofster, Klaus-Achim : Die Bedeutung der Baublockstatistik der Bevölkerungsdichte für die Stadtgeoraphie von Berlin. Die Erde, 92. Jg., Heft 2, 1961, S. 133 141

都市の内部構造を示す指標として，小区画の資料 単位による人口密度は極めて有用である。この観点 から, 1956 年のベルリンの建築ブロック別資料を取 り上ゲ，1934 年の H. Louis の研究と比較する.

結果として 1956 年の人口密度パターンは，1934 年の景観地域パターンと根本的には同一である。し かし部分的には重要な変化が見られた。

第 1 に，核心部の Alte City の人口密展の激減で あり， 1 方样当たりほぼ 6 千人以下に低下した。こ れは，1875 年の Böcken 調查の $2 \sim 8$ 万人，1925 年 の Lyden 調査の $54 \sim 4$ 万人より継続する長期变化
の延長である。この意味の人口低密地は，GroßenStern, Alexander Platz, Lehrer Bohnhot, Halleschen Tor に東西南北を限られた地域である。

これに反して, 人口の高密地は Der Willhelmische Großstadt Gürtel であり，4～15万人／方䊅の高密度 を示し，ベルリンの $2 / 3$ の居住が集中している.こ れは，戦争による破壤後の残存機能の分割などをへ て，中心部を团む形というより，7つの Nebencity の部分都市型式に成育しつつある。それらの間に介 在するのけ工業地区である。

最も急速な人口密度增加は，その外側のAußen 
Holford, William, Sir : Brasilia; The Federal Capital of Brazil. Geogr. Jour., Vol. CXXVIII, Part I, 1962, pp. $15 \sim 18$

ブラジルの遷都問題は, 1789 年に氺ける国家中央 への最初の遷都案いらい, 多くの計画と調査の長い 歴史をへて，1960年 4 月 20 日遂に正式起工式を見 るに至つた。

1957 年の Lucio Costa による Pilot Plan の以前

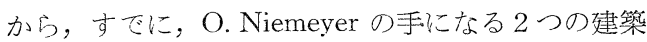
物, 大統領官邸と公式ホテル（または国立病院セン タ一)が着工されていたが,これらはたでちにCosta

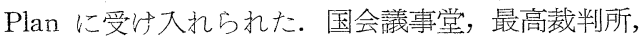
大統領政務所を三角に配置した特色ある中心地区に 続いて, Government Avenue の両側には内閣, 銀 行，六教会などが立び，その両翼は市民区として劇 場，病院などを混じえる共同掞よび個人住宅地に当 てられている，徒歩よりへリコプターに至るまでの
すべての交通能率起計画の基本に置くこの都市では， 徒歩者と車は全く隔絶され，主要道路に平面交叉は ない.トラックなどの重交通は一部で異なつた平面 に分離されている.

Brasilia の建設は進文，すでに 10 万人以上の居 住が実現された．行政とホワイトカラーの全く計画 的な集中であるこの町では，反面，すべてがあまり にも機械的に整然とされ，社会的，歴史的な適当な ふん囲気的背景の欠如がひつの社会的問題点とも なる.しかし，この点に関しても，現在の赤い埃の 町にはすでに植樹か開始された。人工湖が完成し， 大使館その他の国際施設の移動して来ることも，ブ ラジル人にとつてはひとつの “既製の事央”の進行 にすぎない。

\section{BuIJ, Harm J. : The Functional Structure and Central Business District of Lourenco Marques, Moca-} mbique. Econ. Geogr., Vol. 38, No. 1, 1962, pp. 56 77

Lourenco Marques は，現在人口 10 万のうち 3 万以上を非アフリカ人口が占める“欧人大陸都市” のひとつである. 1502 年の発見いらい, ポルトガル の重要な要塞と交易の地として度重なるアフリカ人 との抗争の中に存続し，1895 年の最終闘争以後南 Rhodesia やTransvaal を後背地に急速に発展した。 比較的良好に計画された都市と言われるこの市の 中心部は，1850 年以来の発展にかかる sand spits の部分であり，入しく周囲のマラリヤ沼沢地により 発展支制約されて来た．現在の碁盤割の広く整然と した街路は 1907 年の首府化いらい着手されたもの であり，高級住宅地は涼しくて高い砂嘴上面を占め ている。また，その斜面を占める港と CBD 地区は， 1914年の現埠頭の建設以後急速に発達したものであ る. $\mathrm{CBD} の$ 精査の結果としては，(1) 北西部の市場
付近のものの貧弱と特殊性，(2) CBD は広い面積は 占めるが，機能分化，便宜能力，事務所街の景観な どの点で未熟なものであること，(3)通勤現象も不明 瞭でアアフリカ人の職場指向はむしろ周辺の工業機 能と港湾地区に向けられていること，などが知れる。 計画された中心街が形に終る外側にアフリカ人 居住地区があつた。しかし，首府化いらい次第に競 走港 Beira を引離す発展が見られた結果，この地区 は急速に拡大し，現在はアフリカ人，欧人，工業機 能の混在地区と化した。これらの動きに伴なつて， 一面では干拓沼沢地に抢ける植物園，公会堂の整備 や，市内至る所の近代的アパート建設なども急速に 進んでいるが，他面，市場地区や港湾地区，工業地 区などの周辺では，至る所にアフリカ人居住地区の スラム化が問題となりつつある.

Mabogunje, Akin : The Growth of Residential Districts in Ibadan, Geogr. Rev., Vol. LII, No. 1, 1962, pp. $56 \sim 77$

Ibadan は Yoruba族が 18〜19 世紀の Fulani 族 侵大によつて南方に移動した際に建設した町のひと
つである. 19 世紀中は種族的闘争に执けるキャンプ として軍人とその奉仕者の町の性格が強かつたが， 
1893 年に英国の統制を受け，次いで今世紀初頭より の鉄道建設とカカオ栽培の発展索契機として急速な 発達を見た。人口は 1856 年に 6 万， 1911 年 17 万， 21 年 24 万， 31 年 39 万となり，現在約 60 万に達し ている.

Ibadan の元来の居住地は中央の丘の上にあり， その空間的発達は各好の雨期に汇濫する河谷を避け て丘から丘へ跳んで行なわれた，建築材料上の制約 のためである. 同時にこの町の人口增加は古い核心 居住地の分裂 fission 現象に支えられてきた。すな わら，アフリカ大家族制を背景とした防御的函型の 同族建築の個別的家屋への分解と，旧中庭利用の建 築促進により単位面積当たりの居住人口は著しく増 加したここの分解を進めたのは，輸出農産業の発展 に伴なう大家族制的自給観念の崩䧇が重要な一因で
あるが，その結果は，現在市の $1 / 3$ の人口が居住する 過密集居住地区として不健康なヨルバ地区が形成さ れた：その中にはカカ才労働者の有閉期居住も多く 含まれる.

これに対して，遠心的発展地区の居住は，元来， 外来者達，ことに交易者や專門的職業従事者により 進められた。しかし，1952 年政治力の英国より Nigeria への移行により，行政，公共抢よび一般サーヴ ィス，農業組織，教育，保健などのすべての機能に 打ける現地系都方居住者の増加は著しく，かれらの 多くが郊外居住に参加した。特に最近は政府の留学 奨励により，現地系青年層が㳄米で專門教育や專門 技術を習得して帰る場合が多く，欧米的生活様式を 憧れるかれらのために，アパートや建売住宅を含む 新住宅地区が急速に形成されつつある。

Manshard, Walther: Die Stadt Kumasi (Ghana). Stadt und Umland in ihren funktionalen Beziehungen,

Erdkunde, Bd. XV, Heft 3, 1961, S. 161 179

Kumasi は 16 世紀の Aschanti 族の居住安定とと もに始まつた丘の上の防御都市であり，その中心地 的地位は Tutu 帝の首府として 17 世紀末〜 18 世紀 初期に確立された. 1901 年に英国との武力抗争に敗 れて，人口わずか 3 千人と急衰したが，以後鉄道の 建設とカカオ栽培の発展を契機として再び発展し， 1911 年に 1.9 万, 1931 年 3.6 万, 1948 年 7 万, 1960 年には 22 万と加速度的な膨脹を続けている.

Kumasi の中心地的諸機能とその社会的奉仕は， 周辺地域の後進的性格の濃厚さの中に極めて強烈な 印象を与える。今世紀初頭に国王を追放されていら い，Aschanti 人が常に熱望し続けてきた精神的拠 り所として，1935 年に再び Aschanti 人の連邦委員 会が Kumasi に設置された. 以後, 行政を初めと する公共機関や金融，教育，保健などの各種の中心 地的奉仕は，同時に，若いガーナ人への職業準備教 育としても極めて重要な役割を果し，官公吏の高比 率が急連にガーナ人化して行つた， そして，経済機 能の主体もサーヴィス中心活動であるこの都市の 回りには，欧米と類似した Umland, Hinterland, Einflußgebiete の 3 層の関係圏構造が明膫に分化し，
相応の下層中心地の階層構造が見られる. 元来 Kumasi 商業の中心は市場であつたが，力カオ生産 の発展などにつれて，組織を欠いた多数の中間率人 を特色とするアフリカ的商業機構は次第に変化し， その結果，市場の近くに欧州系大墑社が立ち並び， 欧系と現地商人を仲介する近東，印度系商業者汃集 中して来ている。

工業機能にまだ見るべきもののないこの地域の諸 都市が，力カ才栽培に関係して Aschanti に流れ込 む資力を背負つて発展したことは疑うべくもない。 しかし，カカオ栽培の盛衰に直接影響されるのは， 実例によつても人口 $1.5 \sim 2$ 万程度以下の小都市の みであり，Kumasi など大規模都市の発達は本質的 に別個の問題を持つ. すなわち，Kumasi について 約言すれば,一开では, 人種, 国家, 宗教, 都市など の地方的共同所有意識を基体とする古いAschanti 領域の精神的基盤があり，他方では，欧州的規範へ の急速な接近の形で進められる赤道アフリカの生活 様式の近代化がある. その両者の結合によつてのみ, 現在の西アフリカの植民的諸都市の急速な発展が理 解されよう。 


\section{図畫目録 (1月10日まで到着の分)}

\section{1. 単行 本}

地理学研究VI，244 真，1962 年 3 月，東京教育大学 地理学教室, 古今書院, 非壳品

Walter Grossmann (1962, Berlin) : Vermessungskunde (1), Stückvermessung und Nivellieren, 144 頁

\section{2. 定期刊行物}

地学雑誌, 71 巻 6 号, 1962 年 11 月

須田 晥: 大陸棚の国土基本調查（1２），保 柳・長谷川：シルク・ロードの地理学的諸問題(2) $(10 \sim 22)$

地理， 7 巻 12 号 $/ 8$ 巻 1 号， 1962 年 12 月 $/ 1963$ 年 1 月

諏訪 彰：日本における火山活動とその対策（11 １8），杉村 新：日本の火山带（19～25），村木 定雄 : 火山斜面の開発（32３7）(以上，12 号), 多田文男: 最近の世界地理学界（ $7 \sim 12)$, 石田 龍次郎：イギリスの地理学 $(13 \sim 18)$, 谷岡武雄: フランスに扮ける人文地理学の近業から（18～ 25), 西川 治：ドイッ地理学界最近の動き $(26$ ３1）, 鴨沢・阪口：最近のソ連の地理学（32〜 10), 木内信蔵: アメリカの地理学 $(41 \sim 46)$, 関 口武：ブラジルの地理学界（47〜53), 石田 寛 : ニュージーランドの地理学界（54～60)

地質学雑誌, 68 巻 806 号, 1962 年 11 月

土・太田・田中・伊藤・北川・白井 : 三河高原周 縁部の段丘の対比（664～665）

地球科学， 62 号，1962 年 9 月

関東口ーム研究会・信州口-ム研究会: 花泉層の 堆積環境とその地質時代について (1)（1１0）， 加藤劳的 : 関東口ーム伲の細砂軽鉱物組成（11～ 20)，石井次郎・近堂裙弘：北海道の第四紀火山 灰打よび軽石堆積物の粘土鉱物（29～45）

人類学染誌， 70 巻 1 号，1962 年 6 月 東京大学 地震研究所营報, 40 号 3 冊, 1962 年 9 月 北海道大学 工学部研究報告，31 号，1962 年 10 月 史苑， 23 巻 1 号， 1962 年 9 月

東京経済大学 人文自然科学論集，1号，1962 年
名城商学, 12 巻 1 乓, 1962 年 10 月

国民経済雑誌，106 巻 6 号，1962 年 12 月

愛媛大学紀要，第 2 部 自然科学（地学），4巻 2 号， 1961 年 10 月

鹿罢島大学 文科報告, 11 号, 史学篇 8 号, 1962 年 10 月

天文月報， 55 巻 12 号，1962 年 12 月

日本民族学，26 号，1962 年 11 月 宗教研究，36 巻 1 輯，1962 年 9 月 自然科学と博物館，29 巻 9 〜 10号，1962 年 9 月 富士国立公園博物館研究報告， 8 号，1962 年 11 月 地下資源研究所報告，2号，1962 年 10 月 工業立地， 1 巻 10 号，1962 年 12 月 東北開発研究， 2 巻 1 号，1962 年 10 月

小川博三 : 近郊農村の晨業構造改善に関する実熊 調査（32３7），小林時三郎：津軽地方に括ける 工業の特質（58６3），安田三代人：山形県の内 陸地带における企業の成立について（98～104）

日本の科学已技術， 3 卷 12 号，1962 年 12 月 人口問題研究所年報, 1962 年

人口閪題研究， 85 号，1962 年 7 月 産業と気象，9巻 8 号，1962 年 8 月 高校地理教育談話会会報，4 号，1962 年 10 月 Memoirs of the Defence Academy, 2 巻 3 号, 1962 年 11 月

The Geographical Journal, 128 巻 3 号, 1962 年 9 月 Donald F. Thomson : Desert Aborigines of Western Australia (3) (262-278), T. J. Chandler : London's Urban Climate (279-302), Coastal Cliffs : Report of a Symposium (303-320)

Geographical Bullentin, 18 号，1962 年 11 月 R. T. Gajda : Mapping Population Density in Canada, with particular reference to Plate 48 , Atlas of Canada, 1957 (5-20), J. Ross Mackay : Pingos of the Pleistocene Mackenzie River Delta Area (21-63), Frank A. Cook and V. G. Raiche : Freeze-thaw Cycles at Resolute, N. W. T (64-78), R. Common: The Geomorphology 
of the Medicine Hat Area (86-107)

WMO Bulletin, 11 巻 4 昼, 1962 年 10 月

Geographische Rundschau, 14 巻 10 号，1962 年 10 月

Hannedore Kahmann : Great Britain's Joining the EEC and the Commonwealth (385-396), Michael Haltenberger : Nature and Culture of the Carpathian Mountains (397-404), Hans Ewald : Derdigen in the Kraichgau-Devolopment of a Rural Community towards an Industrial Settlement(405-412), Axel Halbach : The Economic Importance of Southwest-Africa within the South-African Republic (413-416)

Portugal, 5 巻 2 号, 1962 年 $7 / 8$ 月

Izvestiya Vsesoyuznovo Geograficheskovo Obschestva, 94 巻 $4 / 5$ 号，1962 年 $8 / 9$ 月

V. L. Vilenkin : Geographers' activities on the realization of nature conservation law (319-320), V. A Balkov : Ural rivers drainage distribution in spring (321-324), V. N. Abrosov : Heterochronism of high humidication periods in humid and arid zones (325-328), A. I. Otreshko : Karst features between Volga river affluents Sok and Samara (329-330), V. I. Orlov : New data on ravine formation (331-332), A. S. Kriukov : Present ravine erosion in towns (333-336), V. V. Aghibalova and V. L. Vilenkin : The Devdorak glacier (339-342) (以上 4 号), A. G. Isachenko : Some methodic instructions on the $U$ SSR landscape map making (380-387), B. S. Khorev and N.A. Rogov: On the ways of development of the former domestic craft industry (414-424), A. I. Tikhomirov : On the utilization of the Ladoga lake heatresources (425-430), $\mathrm{H}$. K. Ulanov : On the anomaly of water temperature and on the underground delivery in the eastern section of Middle Caspian Sea (431-
434）（以上 5 号）

Izvestiya Akademii Nauk SSSR, 5 号，1962年 10 月

M. I. L'vovich : Water balance and its zonal peculiarities (3-13), Y. V. Spiridonova : Mean yearly regime of atmospheric circulation in Northern Hemisphere (14-21), S. S. Konovalenko : Formation and classification of alluvial placers (22-33), Sh. Tsegmid: Natural regions of the Mongolian People's Republic (34-41), I. P. Gerasimov: To lower and minimize the influence of natural phenomena on our agriculture (43-5 1), D. L. Armand: Quantitative estimation of lands and land cadastres (52-57), S. I. Silvestrov : Land protection against erosion in connection with the intensification of agriculture (58$63)$, V. N. Kunin : Loval water and agricultural development in deserts (77-82), G. A. Avsyuk: Artificial magnification of the melting of mountains glaciers with a view to increased run-off of the rivers in middle Asia (83-89), M. B. Mazanova : Marine transport as a branch of the all-Union specialization of large economic regions (95-101)

Journal (Stanford reseach institute), 5 号，1961 年 Brill's News, 1962 年

3. 別刷り，その他

立教大学地理学研究会 : みずしま一大工業が地域 諸産業に及ぼす影響，68 頁，1962 年 11 月

竹内常行：玉川上水と武蔵野台地，早稻田大学教育 学部学術研究 第 11 号, 1962 年

谷口信一 : 問寒別川流域の森林経営と保全に関する 基礎的研究一問寒別川流域森林の測樹学的研究， 演習林業務資料 第 4 号，1962 年 9 月

人口問題研究所 : 人口变動と経済成長に関する序説， 研究資料 第 149 号，1962 年 4 月 


\section{佐藤弘君の逝去を婥导}

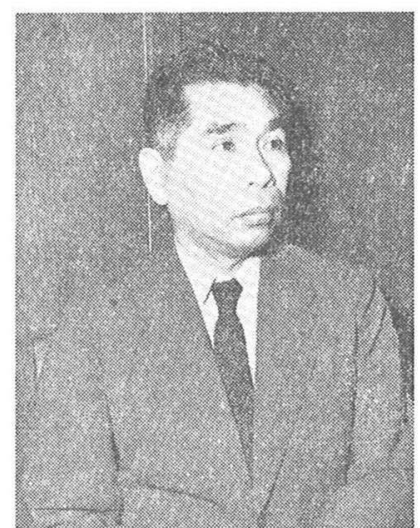

昭和 36 年 12 月 23 日，君体京下北沢の自宅に おいて，全快祈念のかい为なく脳卒中再発のため65 歳をむつて大往生された，慎んで哀悼の意を表す る.

大正 8 年東京帝国大学で地質学科から地理学科が 分離されるや，いち早く山崎直方先生のもとに馳せ 参じた一人である。青年時代には「䛳は学者で往こ うか，筆で立とうか，それとも前掛で往こうか」と 淺らしたことがある。それほど君は多方面に活躍し 得る天賦の資をもち，自らも若くして自負していた ようだ。

君伳事にこだわうず，開放的であり野人的な表 現のうちにユーモアを混えて，常に気楽さと親しさ

$$
\text { 飯本信之 }
$$

をむつて相手在鬿了する特質をもち合わせていた。 また優れた洞察力と，睃敏さをり備えていたことは 誰当が知る所である。

これ等の資性が，地理学界に，一般社会に君の活 動の足跡を大ならしめた所以であろう。中で当明㪿 な頭脳はまず欧米の近代経済地理学をわが国に紹介 し，ついでこのオ面の幾多の著書や論文を表わし， 君をしてわが国における該分野の創始者たらしめた。

やがて泾済地理学会長に推されるや，いよいよそ の手腕を発揮した。

さらに君の偉大な業績は経済地理学の实祭社会化 の面にあるといえよう、君け一橋大学教授在職中は 勿論，同大学の名䇾教授，日本工業立地センター垡 事長となるや，経済地理学の社会化实現老强力に推 進し，その效果をおさめつつあつた。農業国から工

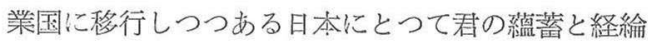
に待つことのいよいよ切なるものがあるとき，君の 他界は地理学界ならびに社会にとつて一大損失とい うべきである。しかし一橋大学走始め，東大，明大 などの諸大学や，その他において直接，間接に君の 指導をうけた幾多の優乔な後継者の現存することを 思い，愁眉をひらく

惟えば共に学空を出て 40 余年，互に多忙な生涯 に追われて，せぬて老後を語り合うべき楽しさも待 たず他界された君を想い衰惜に堪えない。

\section{佐藤 弘君著作目録}

\section{主な論文・抄録}

On the Palisade in Manchuria. Jap. Jour. Geol.

Geogr. 3, 1929

交替作用の法則. 地理詳. 5, 1929

本邦における街村の分布. 地理評. 6, 1930

経済地理より見たる満州の国土計画. 大同学院論 叢 3, 1932

経渢地琶学に於访る交替作用の理論. 東京商大研 究年報「経済学研究」5,1937
ソ連の石炭資源. 一橋論丵 1,1938

碁河の風土的性格. 一憍論對 2,1938

政治地理学関係文献. 一橋論諩 4, 1939

商品出迴り期の研究. 東京摘大研究年報「商学研

究」 5,1940

太平洋の地政治学. 一橋論諁 7,1941

北支・中支の国土計画論。一橋論丵 11,1943

Study on the Palisade in Manchuria. Ann. Hitotsubashi Academy 1, 1951

Waste の原則. 率品研究 7, 1951 
経済地理学の諸問題. 経済研究 5,1954

産業配置論の現代的意義. 通墑産業研究 4, 1956

埼玉県工業立地の現況と将来(編), 埼玉県庁, 1956

三雷罢地域振興圾画調查報告書(編)，三重県广了， 1957

アメリカの経済地理: 日本生産性本部 産業立地 専門視察団報告畫(編)，1958

工策種別による立地条件，用地，施設についての 研究(編)，日本任宅公団，1958

わ加国に频ける工等集積(編)，日本生産性本部， 1960

南九州に扮ける士非開発基礎調查(編)，1960

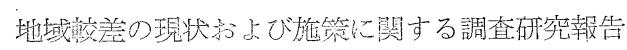
書(編)，日本生産㤬本部，1961

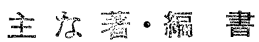

1924 人文地些㦈話, 古文館

1929 政洽経滴坡理学，古今畫院

1930 世界経済地理（商学全集 38），千倉書房

1930 経溗地理学概諭, 古今書院

1931 䰜品地理（経済学全焦 38），改造社

1931 世界政治経済地理統訫!, 1931 年版（佐々木彦 一郎。国松久弥と共緑)，共立社

1931 経済堆理学に於ける文化階梯と経済階梯（岩

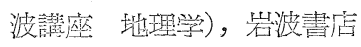

1931 産策貿易, 培風館

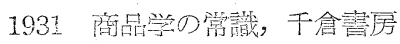

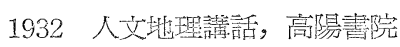

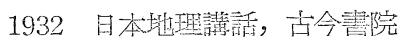

1933 パッサルゲ：景観と文化の発達（国松入弥と 其抄䛊)，古今畫院

1933 経济地理器総諭（経済学全集 62），改造社

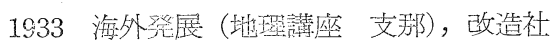

1934 人文地琵六講，高隄畫院

1934 産業地埕管見，古今書院

1935 瞴㫛学概説，同文館
1935 世界経済地理講話, 古今畫院

1935 経済地瑟概説（国松火弥と共著），三省堂

1936 日本国勢地榃，三省堂

1936 最近の経済地理学, 古今書院

1938 日本の戦時資源と日満支ブロック（上田貞次 郎編：戦時経済講話)，科学主義工業社

1938 北支・シベリア・蒙古，三省堂

1938 原料経済（戦時・準戦時経済講話 2), 改造社

1939 経済ブロックと大陸, 古今畫院

1939 政治地理学概論, 柁谷畫院

1940 興西経済地理（ラジオ新書），日本放送出版 協会

1941 自然と経済（新経済学全集 30），日本奡論社

1942 南淎の経済地理（飯本信之と共編：南洋地理 大系1)，ダイヤモンド社

1942 海南島総論 (同上 2 )

1942 東印度総論（同上 5)

1942 嫁洲総論（同上 8)

1943 大呆東の特殊資源, 大東西出版社

1944 大東亜地政論（国松久弥と共著：国防経済学 体系)，㛜松堂畫店

1948 経済地理学原論, 隶海書店

1948 経済地理通論，同文館

1949 商品学入門, 千倉畫房

1949 自然と経済，三省堂

1950 歒業地理（青木外志雄と共著：現代墑学全集 5)，春秋社

1950 新しい世界（国松・除野・田沢・青木と共 編)，三省堂

1951 経済地理, 新紀元社

1952 体系敵品辞典（石井・大越・上坂・永井と共 編)，東洋経済新報社

1954 続体系商品辞典 (同上)，東洋経済新報社

1955 経済地理学総論 (新地理学講座 6), 朝倉書店

1956 人文地理, 弘文社

1959 商品大辞典（石井・大越・上坂・永井と共 編)，東洋経済新報社 
佐藤弘君略歴

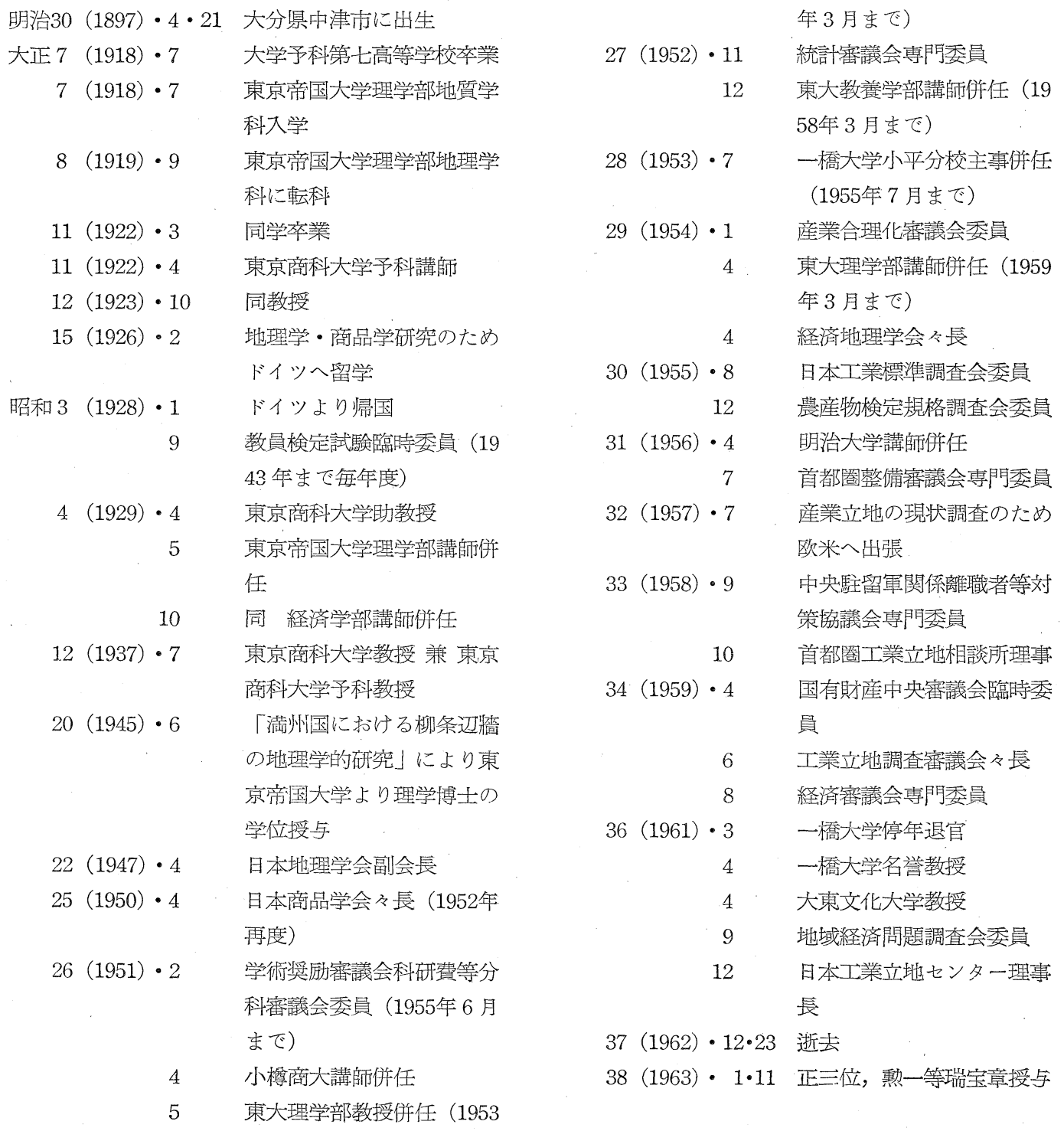




$$
\text { 学界消息 }
$$

\section{日本地理学界関係}

常任委員会 12 月 8 日（土）竹 4 時 30 分 6 時（東京大学地理学教室） 1）表彰規程の検討 お よび秋季大会の反省。2）正会員 3 名・準会員 2 名 の入会，正会員より準会員への変更 1 名，退会 1 名 を承認した。

12 月 21 日 (金) 午後 5 時〜 7 時 (早稻田大学教 育学部竹内研究室） 1）春季大会の件を議し，2） 正会員 4 名，準会員 3 名の入会を承認した.

12月 29 日 臨時常任委員会支開き，九学会 38 年度 調査についての相談をした。

庶務委員会 12 月 3 日（月）午後 4 時 30 分 6 時（東京教育大学地理学教窒）表彰規程案につい て議した。

12 月例会 12 月 8 日 (土）午後 1 時 30 分 4 時 （東京大学地理学教室）講演：1）小笠原義勝君 ～国際百万分の一世界地図，2）小摆䉷君〜酉アジ アの水資源と石油資源一イラン，クェート，アラブ 連合の旅から一・なお，たまたま来日中のG，T。 トレワーサ氏（ウィスコンシン大）も参会した. 地図学研究委員会 12 月 8 日 (土) 午後 4 時 30

\section{他 学 会 関 係}

島根地理学会昭和 37 年 12 月 8 日午後 1 時 30 分より，松江市第一中学校にて開催された. シンポ ジウム：「地理教育」—題目：「野外観察の方法 と笑践」〈提案者〉1) 佐々木茂福 (大東中学) .
分より（東京大学地理学教窒）委員会の運営, 研究課題とその分担につくて議した。

応用地形研究委員会 12 月 15 日（土）午後 2 時 ～5 時（扰茶の水女子大学地理学教室） 1) 島 宏君 : 東京都の地形構造と土木建築物，特に橋梁の 耐震性との関係について，2）次回は1月 26 日 (土)， 木下良作君が河川の蛇行形態について研究発表の予 定. な打，2 月中に島 宏君の発表に伴う現地見学 実施老予定.

災害研究委員会 12 月 15 日（土）午後 1 時 30 分 より（東京大学地理学教室）発表 : 岩塚守公君 「垈害研究のう法論に関する三，三の問題」

会員消息設楽 宪君（広島大）は，昭和 37 年 11 月 1 日付で東北大学理学部助教授に転任，藤原 健蔵君（宋北大）は昭和 37 年 11 月 1 日付で，広島 大学教養部専任講師に転任した。田中薰君（成城大） は神戸大学名誉教授に推蔍された。松井武敏君（名 古屋大）怊昭和 37 年 11 月 1 日付で，名古屋大学文 学部長に任ぜられた。矢橋謙一郎君は海外視察のた め，昭和 37 年 10 月 18 日アメリカに向けて出発した。

嘉本恵吉 (海潮中学)：鄉土学習の実践例，2）梶谷 嚴（島大付中）：野外観察の諸問題，3）山田謙三 (大東高校)：郷土学習指導について 


\section{テーマ別抄録}

都市・集落に関する論文抄録（正井泰夫）I29～I 3I，都市関係，特に世界の都市化（渡辺良雄） I $3 \mathrm{I}$ $\sim 134$

図書目録

佐藤 弘君の逝去を悼む（飯本信之）

学 界 消 息

\section{会告}

2 月例会

日時: 2 月 9 日 (土)，午後 1 時 30 分より

場所 : 東大地理学教室

講演 : P.シェラー君〈日本とドイツの都市〉

\section{春季大会エクスカーションとつけて}

春季大会では，つぎの 8 班のエクスカーションを行ないます．参加希望の会員は，本号添付の申込書 により，期日（2月 28 日）に抢くれぬようにお申し込み下さい.なお今回は，特別に貸切バスなどの 予約を必要とせず，しかも実のある討議を行なえるように，小人数の班を多く計画しました。

第 1 班（4月 8 日）秦野盆地 [案内者：横田忠夫君]

（1）秦野駅前集合（9.30 頃）一専売公社タバコ工場と工場団地の見学一温室・タバコ作・酪農・宅地 化などの進んだ部落で聞取り調査と討議一秦野駅前解散 (17.00 頃)

(2) 定員 約 10 名

(3) 費用 小型バス使用の場合約 200 円

第 2 班（4月 8 日）熊谷・寄居地力 [案内者 : 三友国五郎・村本達郎両君他]

(1) 熊谷駅前集合 $(9.30$ 頃) 一六揠ローリングダム一寄居一円田湖一鉢形城址一櫛引開拓地一浅間山 一深谷駅前解散

(2) 定員 約 15 名

（8）費用 小型バス使用の場合約 350 円

第 3 班（4月 8 ・9日）富岡・妙義・安中地力[案内者：有末武夫・斉藤叶吉・村木定雄 3 君]

(1) 高崎駅前集合一富岡市製系工場一下仁田町コンニャク製粉工場一妙義山第一石門・妙義町(宿泊) 一松井田町ベントナイト工場一碓水関址一安中市東邦亜鉛工場他一付近の果樹栽培他一板舅養鯉業一高 崎駅前解散

（2）定員 約 40 名（群馬大バス使用の予定）

(3) 費用 約 1,300 円

第 4 班 (4月 8・9日) 大子・袋田地方 [案内者 : 桜并明俊・堀口友一両喏〕

（1）上野駅集合一水戸経由大子駅一大子付近調査一袋田温泉（宿泊）一袋田付近調査一大子駅前解散

(2) 定員 約 15 名

(3) 費用 約 1,700 円

第 5 班（4月 $8 \cdot 9$ 日）下田・南伊豆地力 [案内者：尾留川正平・山本正三両君]

（1）東京駅湘南線発車ホーム 9.00 集合一下田駅一德姿山（下田漁港，須崎海蝕台地の土地利用）一白 浜・板戸部落 (テングサ採取とビニール花栽培) 一柿崎間戸浜 (半農半漁 $\rightarrow$ 近郊住宅地 $\rightarrow$ ホテル地区) 一 下田(市内見学，缩泊)一下加茂(温泉熱の利用)一大瀬(有用植物園，ビニール花樹栽培) 一長津吕・石廊 崎・風待港で昼食後解散（下田には 14 時頃帰り，17 時頃東京につくことができる)

(2) 定員 約 12 名

（3）費用 約 2,300 円（但し 8 日の昼食は携行のこと） 
第 6 班 (4月 8 -9 日) 富土山南麓〔案内者 : 浅井辰郎・三井嘉都夫両君〕

(1) 三島駅東海道線改札出口 11.10 集合一三島市(解㛁の滝と湧水)一沼津市 (地下水)一吉原市 (県製 紙試験所)一田子浦港 (地形と水)一田子浦ホテル(宿泊)一富士市 (旭化成工場)一白糸滝一猪頭養筩場一 富士宫駅前解散（15.30 頃）

(2) 定員 約 45 名

（3）費用 約 2,500円（但し 8 日の昼食は携行のこと）

第 7 班（4月 8・9日）霧ガ峯・諏訪湖地才〔案内者 : 岩塚守公・鈴木秀夫・百瀬有郎 3 君〕

(1) 新宿駅集合一沿線の地形・気候景観々察一上諏訪駅一霧ガ峯(宿泊)一霧ガ举の構造士・火山地形 などの観察討議一現地で解散

(2) 定員 約 20 名

(3) 費用 約 2,500 円

第 8 班（4月 8 日）東京〔案内者 : 正井泰夫・山鹿誠次・㴟辺良雄 3 君〕

(1) 東京で目下進行中の諸建設工事を，計画ならびに実施現況の両面について調査討議する（貸切 バスまたは一般交通機関を利用）

(2) 定員 約 20 名

(3) 費用 約 600 円

注 (1) 各班とも，費用は集合から解散までの分で，それ以前および以後の交通費などは含まれませ ん.また金額は概算で，参加者の人数などによって若干変わることがあります.

（2）参加申込みは，第一志望の班の申込金（金額は申込用紙に記入してあります）をそえて，本号添 付の用紙で 2 月 28 日 (必着) までにお申込み下さい，申込金は参加費用の一部に充当されますが，申込 み後参加を取消されてもお返しできません。

日本地理学会大会準備委員会

37 年度本誌の刊行費の一部は，37 年度文部省研究成果刊行費補助金によつた。ここに銘記して謝意 を表す。

日本地理学会

1963年（昭和 38 年） 2 月 1 日発行

東京都文京区本富士町一 東京大学 理学部 地理学教室内

\section{地 理 学 評 論}

第 36 卷

第 2 号

定価 160 円

送料 12 円
日 本 地 理 学 会

(C) 電話 (812) 2111 内線 3288 振替東京 12578 番

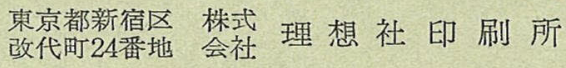

$$
\text { 株式古今 書 院 }
$$

東京都千代田区神田酸河台 2 10 振替東京 35340 番 電話 (291) 2757

(201) 2866 